\title{
Photocatalytic Degradation of Skim-Latex-Vapor Odor Using Iron-Doped Zinc Oxide
}

\author{
Omar Muktaridha ${ }^{1}$, Muhammad Adlim ${ }^{1,2^{*}}$, Suhendrayatna ${ }^{3}$, Ismail ${ }^{4}$, \\ Noor Hana Hanif Abu Bakar ${ }^{5}$ \\ ${ }^{1}$ Graduate School of Mathematics and Applied Science, Universitas Syiah Kuala, Darussalam Banda Aceh \\ 23111, Indonesia \\ ${ }^{2}$ Chemistry Department, FKIP, Universitas Syiah Kuala, Darussalam Banda Aceh 23111, Indonesia \\ ${ }^{3}$ Chemical Engineering Department, Faculty of Engineering, Universitas Syiah Kuala, Darussalam, Banda \\ Aceh 23111, Indonesia \\ ${ }^{4}$ Physics Department, Faculty of Math and Natural Science, Universitas Syiah Kuala, Darussalam Banda \\ Aceh 23111, Indonesia \\ ${ }^{5}$ School of Chemical Science, University Sains Malaysia, 11800 USM, Penang, Malaysia
}

\begin{abstract}
The photocatalytic degradation of the vapor odor of skim natural rubber latex, which is composed of volatile organic compounds (VOCs-NR), was conducted using iron-doped zinc oxide (Fe-ZnO) photocatalyst nanoparticles. The research objectives were to study the photocatalyst, to develop the photocatalytic reactor used for the photodegradation of VOCs-NR, and to analyze the odor reduction of the degraded VOCs-NR. Fe-ZnO was prepared by the sol-gel method and immobilized onto fiberglass cloth as the support material, followed by annealing. The Fe- $\mathrm{ZnO}$ nanoparticles were dispersed on the fiberglass surface. A photocatalytic reactor was developed for the gas phase. The research findings showed that gas chromatography-mass spectroscopy detected 24 dominant chemical components in the VOC-NR stock before photocatalytic degradation. The components decreased to 11 after $30 \mathrm{~min}$, only 3 components remained after $40 \mathrm{~min}$ of the photocatalytic process, and no component was observed after $80 \mathrm{~min}$ of photoirradiation. An organoleptic test was conducted to validate that the odor degraded to a very low level.
\end{abstract}

Keywords: Degradation; Fe-Zn0; Odor; Photocatalyst; Sol-gel

\section{Introduction}

According to statistics, the world's natural rubber production in 2019 was 13.804 million tons, which will increase by $2.7 \%$ annually (Businesswire, 2020). During rubber processing, waste is produced in almost every step: cleaning, coagulant dipping, drying, latex dipping, leaching, beading, vulcanizing, post leaching, slurry dipping, and stripping. This waste contains volatile organic compounds (VOCs), a severe air pollutant that cannot be easily eliminated from waste treatment plants. The presence of VOCs produces bad odor, which is caused by the microorganism degradation of organic materials present in natural rubber, such as glucose, protein, and lipids (Juntarachat et al., 2013). This lousy odor in rubberfactories is disturbing and degrades the quality of life of the surrounding community, as reported by detik.com (Hidayat, 2017). Many similar cases occur at different locations, 
which indicates the serious problem in the rubber production globally.

Waste treatments in rubber factories usually focus on liquid waste (Mokhtar et al., 2015). A new smoke chamber prototype for rubber latex sheets was developed by Dejchanchaiwong et al. (2019). However, the smoke chamber prototype was not tested to eliminate the skim latex odor, especially during the rubber drying process. The odor treatment methods in industries usually involve materials such as activated carbon, biofilters, and biotrickling(Komala et al., 2013; Pan et al., 2018). Activated carbon only adsorbs and accumulates pollutants in the pores; however, it does not eliminate odor. Biopond and biotrickling use microorganisms to degrade the organic compounds; however, these compounds must be wet or under high humidity conditions in the gas phase. Thereby, odor treatment in the gas phase remains unresolved.

Zinc oxide $(\mathrm{ZnO})$ photocatalysts have proven to degrade many VOCs effectively. Buazar et al. (2015) found that ZnO/hydroxyapatite successfully degrades 2mercaptobenzoxazole, which is an unpleasant odorous organosulfur pollutant. Maurer and Koziel (2019) reported that the production of carbon dioxide $\left(\mathrm{CO}_{2}\right)$ increases significantly during the photodegradation process. Fotiou et al. (2016) studied the photodegradation of cyanotoxins in an aqueous phase and found the involvement of radical hydroxyl $(\bullet \mathrm{OH})$ and radical oxygen $\left(\bullet 0^{-}\right)$in the reaction, as indicated by the scavenger treatment. Unlike the microorganism treatment, photocatalysts are usually more compatible with higher temperature fluctuations and toxic environments. In several cases, the catalyst can also be recovered, and the pollutant is converted into harmless compounds, such as $\mathrm{CO}_{2}$ and $\mathrm{H}_{2} \mathrm{O}$, through the reduction-oxidation process (Bechambi et al., 2016).

In this study, iron-doped $\mathrm{ZnO}(\mathrm{Fe}-\mathrm{ZnO})$ was used to reduce the vapor odor of skim latex as a VOC in the gas phase, which is different from most $\mathrm{ZnO}$ photocatalytic tests that were conducted in the liquid phase using a dye solution as the substrate. Slamet et al. (2017) reported a gas-phase photocatalysis; however it was for methylcyclohexane, not for skim latex. A common photocatalytic test has been conducted for the degradation of methylene blue and other dye solutions (Bousslama et al., 2017; Rahman et al., 2018).

In the previous study, instead of the powder form, Fe-ZnO was immobilized onto a fiberglass cloth to make it compatible in the gas phase (Omar et al., 2020). Fiberglass cloth, with a large surface area, is an ideal temperature-resistant support material to disperse the catalyst particles, as the catalyst preparation involves annealing at high temperature. The prototype of a new photocatalytic reactor for skim- latex odor degradation was designed and tested. This study focuses on the preparation, characterization, and immobilization of this photocatalyst. In addition, the photocatalytic activity and reactor prototype are explored to reduce the skim latex odor.

\section{Methods}

\subsection{Materials and VOC-NR Analysis Equipment}

Zinc acetate hexahydrate $\left(\mathrm{Zn}\left(\mathrm{NO}_{3}\right)_{2} \cdot 6 \mathrm{H}_{2} \mathrm{O}\right)$, iron nitrate nonahydrate $\left(\mathrm{Fe}\left(\mathrm{NO}_{3}\right)_{3} \cdot 9 \mathrm{H}_{2} \mathrm{O}\right)$, and medium-molecular-weight chitosan were purchased from Sigma Aldrich (Germany). Latex was taken directly from the plantation in Lamno, Aceh Jaya, Indonesia (Coordinates: 5.138662, 95.352219) (Google Map, 2021). Acetic acid was purchased from Merck (Germany) and used without further purification. The VOC-NR samples were analyzed using gas chromatography-mass spectroscopy (GC-MS) of a TSQTM 9000 triple quadrupole and semi-polar column. 


\subsection{Preparation of Fe- $\mathrm{ZnO}$}

The chitosan solution was previously prepared by dissolving $0.6 \mathrm{~g}$ of chitosan flakes (medium molecular weight) in $100 \mathrm{~mL}$ of a $1.5 \%$ aqueous acetic acid solution (Adlim et al., 2019). The Fe- $\mathrm{ZnO}$ catalyst was prepared by gradually dissolving $29.8 \mathrm{~g}$ of a $\mathrm{Zn}\left(\mathrm{NO}_{3}\right)_{2} \cdot 6 \mathrm{H}_{2} \mathrm{O}$ crystal into $100 \mathrm{~mL}$ of the chitosan solution with stirring. While continuously stirring, a crystal of $\mathrm{Fe}\left(\mathrm{NO}_{3}\right)_{3} \cdot 9 \mathrm{H}_{2} \mathrm{O}(0.4038 \mathrm{~g})$ was gently added to this solution. This method is a modification of a previously reported method (Yusof et al., 2019), where ZnO was prepared using a chitosan stabilizer with $\mathrm{NaOH}$ as the precipitated agent. The solution was continuously stirred for $2 \mathrm{~h}$ and maintained at ambient temperature for $24 \mathrm{~h}$ to facilitate condensation. The concentrations of $\mathrm{Zn}^{2+}$ and $\mathrm{Fe}^{3+}$ in the solution were 1 and $0.01 \mathrm{M}$, respectively ( $1 \%$ dopant). The solution was evenly smeared five times onto the fiberglass cloth surface (dimensions of $15 \mathrm{~cm} \times 9 \mathrm{~cm}$ ) before air drying for $48 \mathrm{~h}$. The coated fiberglass cloth was dried in an oven at $120^{\circ} \mathrm{C}$ to produce xerogel and then calcined at $500^{\circ} \mathrm{C}$ for $2 \mathrm{~h}$ to grow the Fe-ZnO crystal. Chitosan, which acted as the stabilizer, had already decomposed at approximately $400^{\circ} \mathrm{C}$ (Adlim, 2004).

\subsection{Characterization of $\mathrm{Fe}-\mathrm{ZnO}$}

The Fe-ZnO crystal was characterized using X-ray diffraction (XRD) spectroscopy to validate the crystallographic phase of Fe-ZnO. Diffuse reflectance spectroscopy was performed for analyzing the Fe-ZnO bandgap, and scanning electron microscopy (SEM) was performed for observing the Fe-ZnO-coated fiberglass surface. The standard procedures followed for each instrumentation are described as follows.

\subsection{Accumulation of Skim Latex Odor Concentrate (VOCs-NR)}

The coagulated skim latex was sliced into bar shapes $(1 \mathrm{~cm} \times 1 \mathrm{~cm} \times 1 \mathrm{~cm})$ with a mean weight of $2 \mathrm{~g}$. Five pieces of the coagulated latex were kept and rubber-shielded in a 100 $\mathrm{mL}$ vial. The entire VOC-NR stock was stored in 45 vials, which were kept shielded from direct sunlight for three weeks in a water bath at room temperature in an open space. The rubber seal of the vial was airtight. Then, $40 \mathrm{~mL}$ vapor was pumped out from each vial by using a syringe and transferred into a photocatalytic reactor until the reactor was filled with $1 \mathrm{~L}$ of vapor.

\subsection{Photocatalytic Reactor Preparation}

The photocatalytic reactor was a customized instrument for gas or vapor catalysis reactions. It comprised three components that were an outer box, a cuboid glass reactor, and a cylindrical immobilized-photocatalyst, as shown in Figure 1. On the inside wall of the outer box, eight ultraviolet lamps (@ 8 watts, $\lambda=365 \mathrm{~nm}$ ) were installed, and two computer-cooler fans were used to control the heat in the box. The glass reactor (dimensions of $10 \mathrm{~cm} \times 10 \mathrm{~cm} \times 20 \mathrm{~cm}$ (height)) was placed inside the outer box. The glass reactor was equipped with a modified vertical stirrer (Figure 1) to circulate vapor homogeneously at $240 \mathrm{rpm}$. A long transparent tape was used as the stirrer agitator. In addition, the reactor had three rubber port inlets for inserting a thermometer and a manometer and for gas injection.

The Fe-ZnO photocatalyst immobilized onto the fiberglass cloth was placed in the middle of the glass reactor. The Fe-ZnO-fiberglass cloth covered the cylindrical support $\varnothing$ $=4.8 \mathrm{~cm} ; \mathrm{h}=9.0 \mathrm{~cm}$ ). The fiberglass cloth containing $\pm 1.69 \mathrm{~g}$ of the catalyst, had a surface area of $135.7 \mathrm{~cm}^{2}$. All ports were sealed using silicon rubber to avoid gas leaks during the photocatalytic reaction. The reactor was designed to facilitate a simple application in a realtime situation. The temperature inside the reactor was recorded to be stable at $29^{\circ} \mathrm{C}$, and no significant pressure change occurred during the vapor injection process. 

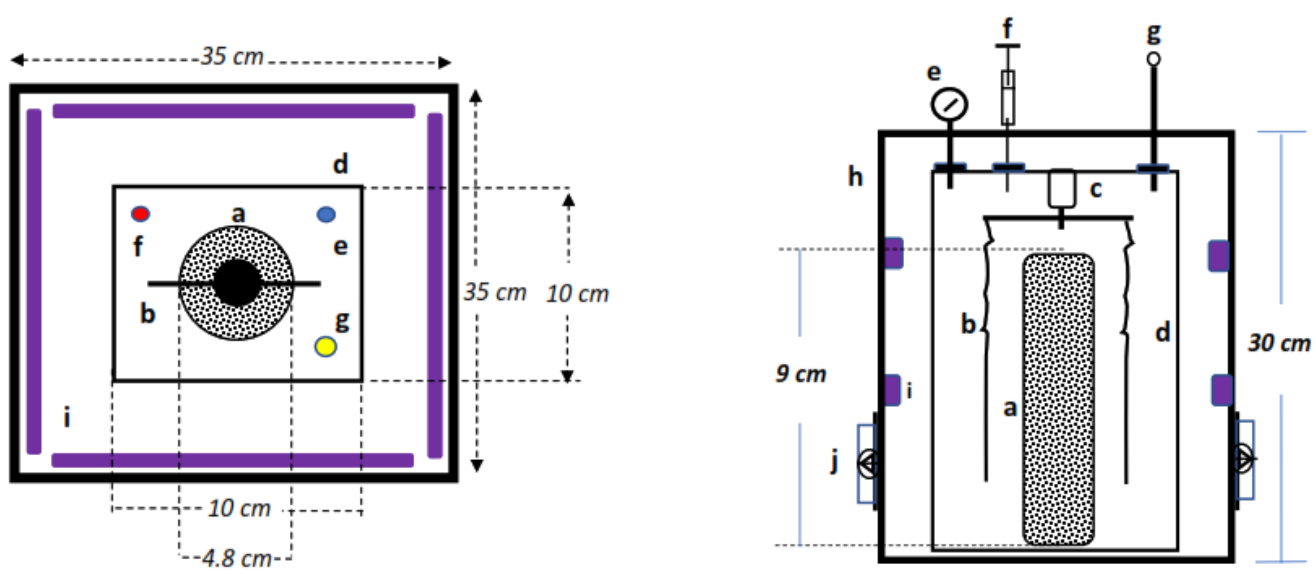

(a) Fe-ZnO-fiberglass cloth cylinder; (b) stirrer-transparent plastic tapes

(c) DC motor vertical stirrer; (d) reactor glass case; (e) mini-barometer

(f) sampling injection-equipped rubber septum port, (g) thermometer

(h) box case; (i) UV lamps; (j) in-out exhaust fans

Figure 1 Diagram of the photocatalytic reactor; top view (left), side view (right)

\subsection{Photocatalytic Degradation of VOCs-NR}

The accumulated VOC-NR vapor and photocatalytic instruments were prepared as described above (Figure 1). As the control sample, $1 \mathrm{~mL}$ of the concentrated vapor was sampled and injected into the GC-MS instrument. Then, $1 \mathrm{~L}$ of the accumulated VOC-NR was injected into the reactor. Before the UV light was turned on, the VOC-NR was stirred under dark conditions. The reaction was run for $240 \mathrm{~min}$ at time intervals of $0,30,40,80,120$, 160,200 , and $240 \mathrm{~min}$. The experiment was repeated by turning the light on for catalytic decomposition.

\subsection{GC-MS Confirmation on VOC-NR Reduction Level}

Each sample was analyzed using a GC-MS instrument under the following conditions. The oven temperature of the instrument was maintained at $40^{\circ} \mathrm{C}$ for $5 \mathrm{~min}$, increased to $250^{\circ} \mathrm{C}$ at a rate of $4^{\circ} \mathrm{C} / \mathrm{min}$, and then maintained at $250^{\circ} \mathrm{C}$ for $10 \mathrm{~min}$. The carrier gas was helium, with a flow rate of $1.5 \mathrm{~mL} / \mathrm{min}$. The detector was set in the full-scan mode, covering a mass range (m/z) of 50-450 amu (Juntarachat et al., 2013).

\subsection{Panelists' Response to Odor Reduction/Organoleptic Test}

Skim latex naturally produces the vapor order without any chemical treatment. The experiment was conducted at normal temperature $\left(29^{\circ} \mathrm{C}\right)$ and pressure $(1 \mathrm{~atm})$. Sampling was performed using a fine-needle syringe to avoid dust suction, and no harmful chemical was detected in the GC-MS data. Ten panelists (six males and four females, aged between 19 and 55 years) volunteered to perform an organoleptic test for the VOC-NR odor level before and after the photocatalytic decomposition. The number of panelists was determined based on a previously reported method (Juntarachat et al., 2013). Before the experiment, in the calibration section, the panelists were required to smell randomly four shield caps containing different VOC-NR concentrations: 0 (empty, no VOC-NR), $5 \mathrm{~mL}, 10$ $\mathrm{mL}$, and concentrated VOC-NR. Each panelist was then required to record the odor level in the organoleptic sheets on a scale of $1-4$, where $1=$ odorless, $2=$ moderate smell, $3=$ bad odor, and 4 = very bad odor. The panelists were also provided additional space in the organoleptic sheet to write different levels from the given-odor-level choices. Then, in the experimental section, they were required to smell three caps that contained VOC-NR. Sampling was carried in three periods that were 0 minute (a control; sample was in dark, 
the photocatalytic reaction has not occurred), 40 and 80 minutes after photocatalytic degradation, respectively. The odor level data were recorded on the organoleptic test sheet for further analysis.

\section{Results and Discussion}

\subsection{Preparation and Characterization of Catalysts}

We have previously promoted a detailed preparation and characterization of $\mathrm{Fe}$ $\mathrm{ZnO}(0 \mathrm{mar}$ et al., 2020). ZnO was prepared with and without a co-precipitation agent before annealing. We found that, without co-precipitation, Fe-ZnO exhibits better characteristic particles. Without co-precipitation, the Fe-ZnO was formed with several steps starting with formation of coordination bond between chitosan amino-groups with $\mathrm{Zn}^{2+}$ and $\mathrm{Fe}^{3+}$. The next step was burning out chitosan and formation Fe-ZnO during annealing. The Fe-ZnO was confirmed with the XRD data (Omar et al., 2020) and verified by Bousslama et al. (2017), as illustrated in Equations 1-4. The particles were highly crystalline with a diameter of $50 \mathrm{~nm}$, according to the Debye-Scherrer calculation, and less aggregated, according to the transmission electron microscopy analysis. In addition, Fe-ZnO was stable during immobilization onto the fiberglass, and no traces of sodium were detected. A JCPDS (036-1451) standard diffractogram confirmed that the $\mathrm{ZnO}$ pattern was similar to a wurtzite structure, as reported by Bousslama et al. (2017). Figure 2 shows the SEM images of the fiberglass before and after $\mathrm{Fe}-\mathrm{ZnO}$ immobilization. Fe-ZnO remained stable even after annealing $\left(500^{\circ} \mathrm{C}, 2 \mathrm{~h}\right)$. Thus, the fiberglass cloth was appropriate supporting material for Fe-ZnO. The interaction between Fe-ZnO and fiberglass is a physical interaction in which the particles are stacked on each thread of the fiberglass (Figure 2). According to the Kubelka-Munk calculation, the bandgap of Fe-ZnO was $3.20 \mathrm{eV}$, which usually exhibits high activity in ultraviolet irradiation (Omar et al., 2020).

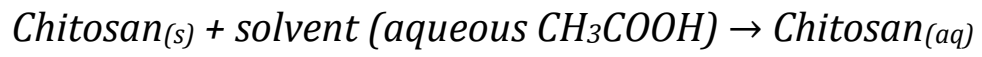

$$
\begin{aligned}
& \text { Chitosan }_{(a q)}+\mathrm{Zn}\left(\mathrm{NO}_{3}\right)_{2(s)}+\mathrm{Fe}\left(\mathrm{NO}_{3}\right)_{3(s)} \rightarrow \mathrm{Chi}-\left(\mathrm{Zn}_{(a q)}^{2+}+\mathrm{Fe}_{(a q)}^{3+}\right)+5 \mathrm{NO}_{3(a q)}^{-} \\
& \text {Heating \& drying } \\
& \mathrm{Chi}-\left(\mathrm{Zn}_{(a q)}^{2+}+\mathrm{Fe}_{(a q)}^{3+}\right)+5 \mathrm{NO}_{3(a q)}^{-} \rightarrow\left[\mathrm{Chi}-\left(\mathrm{Zn}^{2+}+\mathrm{Fe}^{3+}\right)+5 \mathrm{NO}_{3}^{-}\right]_{S} \\
& \text { annealing process } \\
& {\left[\mathrm{Chi}-\left(\mathrm{Zn}^{2+}+\mathrm{Fe}^{3+}\right)+5 \mathrm{NO}_{3}^{-}\right]_{s} \rightarrow \mathrm{Fe}-\mathrm{ZnO}_{(s)}+5 \mathrm{NO}_{2(g)}+2 \mathrm{O}_{2(\mathrm{~g})}+} \\
& \text { (chi-decomposition) }
\end{aligned}
$$

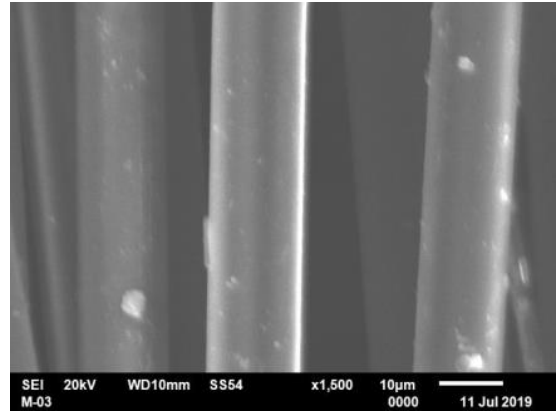

(a)

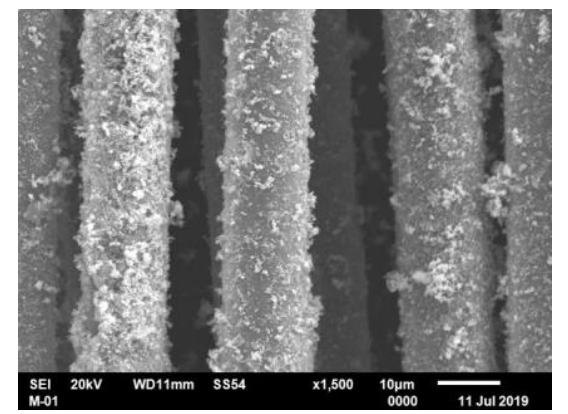

(b)

Figure 2 Surface images of fiberglass cloth before (a) and after (b) immobilization with Fe-ZnO 


\subsection{Photocatalytic Test and the Characterization}

The GC-MS chromatograms were interpreted based on the library data without using a standard solution. According to the GC-MS library, approximately 24 different components are identified in the concentrated vapor. These components are dominated by fatty acid compounds and alcohol derivatives, as tabulated in Table 1.

Table 1 Identified compounds of VOCs-NR based on the timeline of photodegradation

\begin{tabular}{|c|c|c|c|c|}
\hline \multicolumn{5}{|c|}{ The compound identified from concentrated VOCs-NR } \\
\hline $\begin{array}{l}\text { Retention } \\
\text { time (min) }\end{array}$ & $\begin{array}{l}\text { SI (Match } \\
\text { factor) }\end{array}$ & $\begin{array}{l}\text { Broad: height } \\
\text { peak }(\%)\end{array}$ & High-probability compounds & Remarks \\
\hline 1.55 & 686 & $1.61: 2.25$ & Butanoic acid & \\
\hline 4.04 & 636 & $0.79: 0.87$ & $\begin{array}{l}\text { D-Fructose, diethyl mercaptan, } \\
\text { pentaacetate }\end{array}$ & \\
\hline 4.62 & 711 & $0.75: 0.81$ & 13,16-Octadecadiynoic acid, methyl ester & \\
\hline 6.71 & 694 & $1.62: 1.45$ & Propane-dioic acid & \\
\hline 37.10 & 739 & $3.64: 1.39$ & 2-Myristynoyl pantetheine & \\
\hline 38.77 & 676 & $0.76: 0.12$ & 10-Heptadecen-8-ynoic acid, methyl ester & \\
\hline 42.37 & 835 & $6.02: 5.79$ & Hexadecenoic acid & \\
\hline 43.22 & 877 & $14.80: 17.32$ & n-Hexadecenoic acid & \\
\hline 46.46 & 871 & $4.51: 5.82$ & 10-Octadecanoic acid, Methyl ester & \\
\hline 47.06 & 723 & $0.85: 1.01$ & Cyclo-propane-dodecenoic acid & \\
\hline 47.33 & 851 & $9.67: 7.95$ & cis-Vaccenic acid & \\
\hline 47.80 & 755 & $0.68: 1.04$ & Dasycarpidan-1-methanol & \\
\hline 48.32 & 694 & $7.19: 5.93$ & Z-8-Methyl-9-tetradecenoic acid & \\
\hline 48.42 & 717 & $11.18: 11.04$ & E,E,Z-1,3,12-Nonadecatriene-5,14-diol & \\
\hline 48.63 & 755 & $0.60: 0.92$ & 1-Heptatriacotanol & \\
\hline 49.16 & 730 & $5.23: 2.21$ & E,E,Z-1,3,12-Nonadecatriene-5,14-diol & \\
\hline 50.24 & 735 & $0.86: 1.34$ & 2-Methyl-E,E-3,13-octadecadien-1-ol & \\
\hline 50.68 & 757 & $1.71: 2.22$ & 9-Octadecenoic acid (Z)-,oxy-ranyl-methyl & \\
\hline 51.38 & 777 & $3.17: 4.44$ & 9-Hexadecenoic acid & \\
\hline 51.76 & 774 & $8.38: 9.42$ & Z-(13,14-Epoxy)tetradec-11-en-1-ol acetate & \\
\hline 52.07 & 734 & $0.68: 0.89$ & oleic acid & \\
\hline 53.46 & 718 & $3.93: 3.42$ & 12-Methyl-E,E-2,13-octadecadien-1-ol & \\
\hline 54.83 & 750 & $3.02: 2.97$ & 17-Pentatriacontene & \\
\hline 58.91 & 765 & $1.30: 1.31$ & Ethyl iso-allocholate & \\
\hline \multicolumn{5}{|c|}{ The identified VOC-NR compounds after 30 min of adsorption-desorption } \\
\hline 35.64 & 665 & $0.79: 0.87$ & 9-Hexadecenoic acid & 0 \\
\hline 38.72 & 669 & $2.80: 0.88$ & $\begin{array}{l}\text { 9,10-Secocholesta-5,7,10(19)-triene- } \\
\text { 3,24,25-triol }\end{array}$ & EL \\
\hline 42.38 & 803 & $17.85: 19.43$ & Hexa-decanoic acid & 0 \\
\hline 43.20 & 808 & $13.07: 18.79$ & n-Hexa-decanoic acid & EL \\
\hline 43.65 & 671 & $8.12: 6.19$ & 1-Hexadecanol & 0 \\
\hline 46.47 & 837 & $12.60: 20.22$ & 10-Octadecenoic acid & 0 \\
\hline 47.31 & 771 & $5.48: 6.71$ & trans-13-Octadecenoic acid & EL \\
\hline 48.34 & 696 & $5.57: 5.02$ & 10-Methyl-8-tetradecen-1-ol acetate & EL \\
\hline 49.21 & 713 & $3.77: 2.81$ & Ethyl iso-allocholate & 0 \\
\hline 51.77 & 736 & $7.52: 10.71$ & 12-Methyl-E,E-2,13-octadecadien-1-ol & 0 \\
\hline 55.26 & 720 & $10.49: 4.39$ & 17-Pentatriacontene & 0 \\
\hline \multicolumn{5}{|c|}{ The identified VOC-NR compounds after 40 min of photodegradation } \\
\hline 58.10 & 689 & $5.70: 8.28$ & $\begin{array}{l}\text { 9,10-Secocholesta-5,7,10(19)-triene- } \\
\text { 3,24,25-triol }\end{array}$ & 0 \\
\hline 58.85 & 698 & $15.95: 23.05$ & Ethyl iso-allocholate & 0 \\
\hline 60.23 & 770 & $68.66: 55.26$ & Stigmasta-3,5-diene & EL \\
\hline
\end{tabular}

(SI index: $>900=$ excellent; $800-900=$ good; $700-800=$ fair $;<600=$ poor)

Origin (0): compound continuously existed, existed later (EL): compound detected in this time

The chromatograms are presented as supplementary data 1 
A fatty acid is a primary compound in VOCs-NR, with n-hexadecenoic acid exhibiting the highest fraction. The alcohol derivative compounds in the form of E,E,Z-1,3,12nonadecatriene-5,14-diol are the secondary compounds. It is implied that the degradation occurs at the fatty acid and protein sites, rather than the latex chemical structure, which has an isoprene chain joint with fatty acid and protein (Sriring et al., 2018).

Compared to the chemical component in concentrated vapor (VOC-NR stock), some of the components (between the retention times of 0 and $10 \mathrm{~min}$ ) disappeared before the photocatalytic reaction commenced $(0 \mathrm{~min})$. Out of the initially detected 24 components, only 11 were observed with significant concentrations; the other 13 appeared in weak concentrations. The 11 components identified were mainly fatty acid derivatives, as listed in Table 1. This phenomenon is attributable to the fact that certain compounds were preliminarily adsorbed by the catalyst as there was a period of $30 \mathrm{~min}$ between injection and photocatalytic light on. However, the absorption no longer continued in the dark experiment.

After 40 min of photocatalytic reaction, many compounds were no longer detected; only three components remained, as shown in Table 1. These compounds exhibited polycyclic structures, which require higher energy to degrade. Typically, a new compound that existed in this degradation period was stigmata-3,5-diene, which has a similar back bond with the other existing compounds, such as ethyl-isoallocholate. Ethyl-isoallocholate was dominant in the composition. In addition, there was a possible structural rearrangement of ethyl-iso-allocholate into stigmasta-3,5-diene. The chemical structures of these components are presented in supplementary data 2. This confirmed the photodegradation process, where the cyclic and polycyclic compounds degraded more gradually than the aliphatic fatty and alcohol compounds, which predominantly existed before $40 \mathrm{~min}$ of degradation. The photodegradation initiated with the formation of $\bullet \mathrm{OH}$ and $\bullet O$ radicals. Then the radicals attack the longer chain and the functional groups of targeted compounds (Rayaroth et al., 2018). After 80 min of photocatalytic degradation, no compounds were detected; probably, the components got converted into $\mathrm{CO}_{2}$ and $\mathrm{H}_{2} \mathrm{O}$, which is an odorless compound. These data imply that the VOCs-NR were successfully degraded using the Fe-ZnO catalyst under UV light $(\lambda=365 \mathrm{~nm})$ irradiation.

In addition, an organoleptic test was also conducted to confirm odor reduction by comparing the odor levels before, during, and after the catalytic photodegradation. The participants responded that the bad smell reduced noticeably with the photocatalytic degradation time, as shown in Figure 3. All respondents agreed that the control sample had the worst odor and marked it as level 4. This is in agreement with the GC-MS data, according to which the control comprised 24 chemical components, which originated from the skim latex vapor. The empathy vial was marked as level 1 or odorless.

Most respondents gave a mean odor level of 3.4 to the sample before photocatalytic degradation ( $0 \mathrm{~min}$ ); thus, the odor level reduced slightly from 4 to 3.4. This reduction indicates either the vapor dilution in the reactor or the catalysts initially adsorbed it in the reactor. After 40 min of photocatalytic reaction, almost all respondents felt that the odor had decreased tremendously to a mean level of 2 . This diminution is attributable to the photodegradation of the smell components of VOCs-NR into $\mathrm{CO}_{2}$ and $\mathrm{H}_{2} \mathrm{O}$, which are odorless. Some respondents could still smell slight odor (at level 1.9) in the sample after 80 min of photodegradation. This level is very low, as the odorless level was 1 and worst level was 4. 


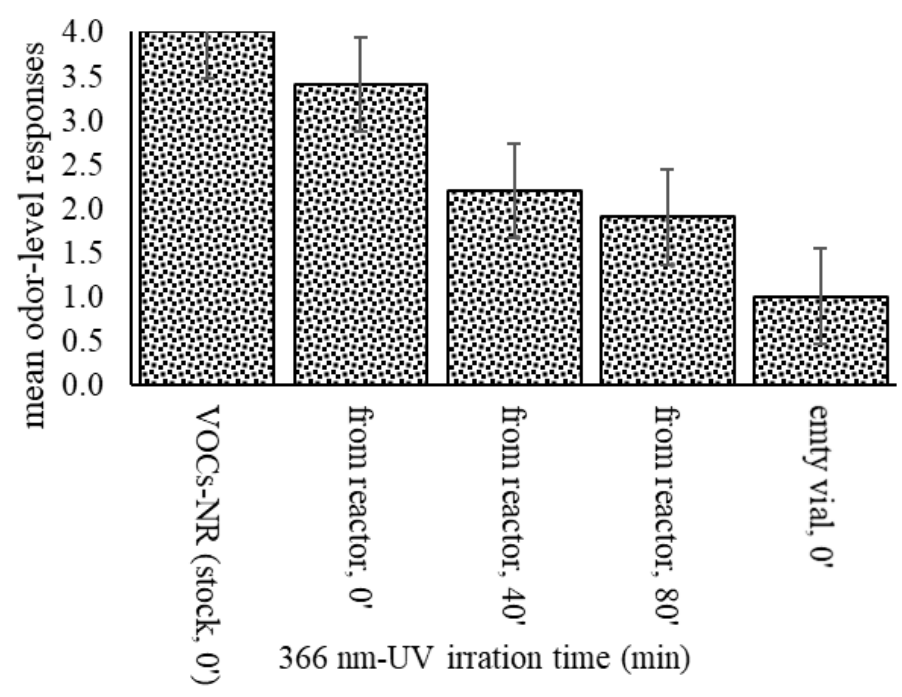

Figure 3 Mean odor level reduction after catalytic photodegradation according to respondents' responses; odor level: $4=$ worst odor, 3 = bad odor, 2 = less odor, 1 = odorless

\section{Conclusions}

Fe-ZnO prepared by the sol-gel method was successfully immobilized in fiberglass cloth. The Fe-ZnO particles were dispersed on the surface of the fiberglass cloth, and some particles were in the nanosize range. The Fe-ZnO photocatalyst prepared using chitosan, as the stabilizer, actively decomposed the VOCs-NR (the skim latex vapor) and reduced the odor level. Odor reduction progressively depended on the characteristics of the chemical components. The catalytic photodegradation progress was monitored by using GC-MS and validated with an organoleptic test. The polycyclic compounds in VOCs-NR took more time to degrade than the aliphatic compounds. Thus, VOC-NR photocatalytic degradation is an essential step for industrial application.

\section{Acknowledgements}

This research was funded by a PRUU-PD research grant from Universitas Syiah Kuala, Darussalam Banda Aceh 23111, the Republic of Indonesia with the grant of "Program Riset Unggulan Unsyiah, Percepatan Doktor" Reg\# 292/UN11/SPK/PNBP/2020. We appreciate Dr Syahidah Akmal Muhammad from the School of Technology Industry, USM for the discussions on the GC-MS.

\section{References}

Adlim, A., 2004. The Synthesis and Characterization of Chitosan-stabilized Mono-and Bimetallic Noble Metals Nano-Sized Colloidal Catalysts and the Catalytic Properties, PhD thesis, USM, Malaysia

Adlim, M., Zarlaida, F., Rahmayani, R.F.I., Wardani, R., 2019. Nutrient Release Properties of a Urea-magnesium-natural Rubber Composite Coated with Chitosan. Environmental Technology \& Innovation, Volume 16, doi: 10.1016/j.eti.2019.100442

Bechambi, O., Jlaiel, L., Najjar, W., Sayadi, S., 2016. Photocatalytic Degradation of Bisphenol $\mathrm{A}$ in the Presence of Ce-ZnO: Evolution of Kinetics, Toxicity and Photodegradation Mechanism. Materials Chemistry and Physics, Volume 173, pp. 95-105

Bousslama, W., Elhouichet, H., Ferid, M., 2017. Enhanced Photocatalytic Activity of Fe Doped ZnO Nanocrystals under Sunlight Irradiation. Optik, Volume 134, pp. 88-98 
Buazar, F., Alipouryan, S., Kroushawi, F., Hosseini, S.A., 2015. Photodegradation of Odorous 2-Mercaptobenzoxazole Through Zinc Oxide/Hydroxyapatite Nanocomposite. Applied Nanoscience, Volume 5, pp. 719-729

Businesswire, 2020. South East Asia Rubber Markets, 2019-2020 Featuring Bridgestone, Michelin, Goodyear, Continental, Sumitomo Rubber Industries, Thai Rubber Latex (Thaitex) and Fenner - ResearchAndMarkets.com. Available Online at https://www.businesswire.com /news/ home/20200427005431/en/South-EastAsia-Rubber-Markets-2019-2020-eaturing.html, Accessed on June 25, 2020

Dejchanchaiwong, R., Kumar, A., Tekasakul, P., 2019. Performance and Economic Analysis of Natural Convection based Rubber Smoking Room for Rubber Cooperatives in Thailand. Renewable Energy, Volume 132, pp. 233-242

Fotiou, T., Triantis, T.M., Kaloudis, T., O’Shea, K.E., Dionysiou, D.D., Hiskia, A., 2016. Assessment of the Roles of Reactive Oxygen Species in the UV and Visible Light Photocatalytic Degradation of Cyanotoxins and Water Taste and Odor Compounds using $\mathrm{CeTiO}_{2}$. Water Research, Volume 90, pp. 52-61

Google. (n.d.). Sapek, Aceh Jaya Regency, Aceh. Available Online at https://goo.gl/maps/EFSJiyxLUMHWeXs46, Accessed on 24th 2021

Hidayat, B., 2017. 8 TahunHirupLimbahPabrikKaret, Warga Desa di Mojokerto Melawan. ( 8 Years of Inhaling Rubber Factory Waste, Villagers in Mojokerto Fight Back) Available Online at https://www.merdeka.com/peristiwa/8-tahun-hirup-limbah-pabrik-karetwarga-desa-di-mojokerto-melawan.html, Accessed on February 10 ${ }^{\text {th }}, 2020$

Juntarachat, N., Bouvier, N., Lepoutre, J.P., Roland, A., Sainte-Beuve, J., Granet, F., Salmon, J.M., Rigou, P., Chalier, P., 2013. Identification by GC-O and GC-MS of New Odorous Compounds in Natural Rubber. Journal of Applied Polymer Science, Volume 130(3), pp. 1863-1872

Komala, P.S., Dewilda, Y., Wulandari, Z., 2013. Biodegradation of Azo Dye Remazol Black 5 by Mono Culture Bacteria with Tempe Industrial Wastewater as Co-substrate. International Journal of Technology, Volume 4(3), pp. 240-248

Maurer, D.L., Koziel, J.A., 2019. On-farm Pilot-scale Testing of Black Ultraviolet Light and Photocatalytic Coating for Mitigation of Odor, Odorous VOCs, and Greenhouse Gases. Chemosphere, Volume 221, pp. 778-784

Mokhtar, N.M., Lau, W.J., Ismail, A.F., Veerasamy, D., 2015. Membrane Distillation Technology for Treatment of Wastewater from Rubber Industry in Malaysia. Procedia CIRP, Volume 26, pp. 792-796

Omar, M., Adlim, M., Maulana, I., Suhendrayatna, S., Ismail, I., 2020. The Preparation and Characterization of Fe-ZnO Nanoparticles Immobilized onto Fiberglass Cloth. Key Engineering Material, Defect and Diffusion Forum, Volume 402, pp. 115-124

Pan, J., Jia, H., Shang, M., Li, Q., Xu, C., Wang, Y., Wu, H., Dong, X., 2018. Effects of Deodorization by Powdered Activated Carbon, $\beta$-cyclodextrin and Yeast on Odor and Functional Properties of Tiger Puffer (Takifugurubripes) Skin Gelatin. International Journal of Biological Macromolecules, Volume 118, pp. 116-123

Rahman, A., Nurjayadi, M., Wartilah, R., Kusrini, E., Prasetyanto, E.A., Degermenci, V., 2018. Enhanced Activity of $\mathrm{TiO}_{2}$ /Natural Zeolite Composite for Degradation of Methyl Orange Under Visible Light Irradiation. International Journal of Technology, Volume 9(6), pp. 1159-1167

Rayaroth, M.P., Aravind, U.K., Aravindakumar, C.T., 2018. Photocatalytic Degradation of Lignocaine in Aqueous Suspension of $\mathrm{TiO}_{2}$ Nanoparticles: Mechanism of Degradation and Mineralization. Journal of Environmental and Chemical Engineering, Volume 6(3), pp. 3556-3564 
Slamet, O., Hendarsa, A., Ratnawati, M.S., 2017. Photodegradation of Methylcyclohexane in Two Phases with Modified-Titania Immobilized on Pumice. International Journal of Technology, Volume 8(1), pp. 27-36

Sriring, M., Nimpaiboon, A., Kumarn, S., Sirisinha, C., Sakdapipanich, J., Toki, S., 2018. Viscoelastic and Mechanical Properties of Large- and Small-particle Natural Rubber Before and After Vulcanization. Polymer Testing, Volume 70, pp. 127-134

Yusof, N.A.A., Zain, N.M., Pauzi, N., 2019. Synthesis of ZnO Nanoparticles with Chitosan as Stabilizing Agent and their Antibacterial Properties against Gram-positive and Gramnegative Bacteria. International Journal of Biological Macromolecules, Volume 124, pp. 1132-1136 